\title{
Allocating Harvests among Polar Bear Stocks in the Beaufort Sea
}

\author{
S.C. AMSTRUP, ${ }^{1,2}$ G.M. DURNER, ${ }^{1}$ I. STIRLING ${ }^{3}$ and T.L. McDONALD ${ }^{4}$
}

(Received 25 October 2004; accepted in revised form 21 January 2005)

\begin{abstract}
Recognition that polar bears are shared by hunters in Canada and Alaska prompted development of the "Polar Bear Management Agreement for the Southern Beaufort Sea." Under this Agreement, the harvest of polar bears from the southern Beaufort Sea (SBS) is shared between Inupiat hunters of Alaska and Inuvialuit hunters of Canada. Quotas for each jurisdiction are to be reviewed annually in light of the best available scientific information. Ideal implementation of the Agreement has been hampered by the inability to quantify geographic overlap among bears from adjacent populations. We applied new analytical procedures to a more extensive radiotelemetry data set than has previously been available to quantify that overlap and thereby improve the efficacy of the Agreement. We constructed a grid over the eastern Chukchi Sea and Beaufort Sea and used twodimensional kernel smoothing to assign probabilities to the distributions of all instrumented bears. A cluster analysis of radio relocation data identified three relatively discrete groups or "populations" of polar bears: the SBS, Chukchi Sea (CS), and northern Beaufort Sea (NBS) populations. With kernel smoothing, we calculated relative probabilities of occurrence for individual members of each population in each cell of our grid. We estimated the uncertainty in probabilities by bootstrapping. Availability of polar bears from each population varied geographically. Near Barrow, Alaska, 50\% of harvested bears are from the CS population and 50\% from the SBS population. Nearly $99 \%$ of the bears taken by Kaktovik hunters are from the SBS. At Tuktoyaktuk, Northwest Territories, Canada, 50\% are from the SBS and 50\% from the NBS population. We displayed the occurrence of bears from each population as probabilities for each cell in our grid and as maps with contour lines delineating changes in relative probability. This new analytical approach will greatly improve the accuracy of allocating harvest quotas among hunting communities and jurisdictions while assuring that harvests remain within the bounds of sustainable yield.
\end{abstract}

Key words: Arctic, Beaufort Sea, boundaries, clustering, harvest allocation, kernel, management, polar bears, Ursus maritimus, population delineation, radiotelemetry, smoothing

RÉSUMÉ. La reconnaissance du fait que l'ours polaire est chassé tant au Canada qu'en Alaska a initié la création de l' 'Accord de gestion de l'ours polaire dans le sud de la mer de Beaufort». En vertu de cet accord, le prélèvement de l'ours polaire du sud de la mer de Beaufort est partagé entre les chasseurs inupiat de l'Alaska et les chasseurs inuvialuit du Canada. Les quotas pour chaque territoire de compétence doivent être révisés sur une base annuelle à la lumière de la meilleure information scientifique disponible. Une parfaite mise en œuvre de l'accord a été rendue difficile en raison de l'impossibilité de quantifier le chevauchement géographique des populations d'ours voisines. En vue de quantifier ce chevauchement et d'améliorer ainsi l'efficacité de l'accord, on a appliqué de nouvelles procédures analytiques à un plus vaste ensemble de données télémétriques qu'on n'avait pu le faire auparavant. On a construit une grille recouvrant l'est de la mer des Tchouktches et la mer de Beaufort, et on a utilisé une méthode de lissage bidimensionnel par noyaux afin d'assigner des probabilités aux distributions de tous les ours appareillés. Une analyse de groupage des données de déplacement obtenues par radiocommunication a révélé trois groupes relativement distincts ou «populations» d'ours polaires, soit celles du sud de la mer de Beaufort (SMB), de la mer des Tchouktches (MT) et du nord de la mer de Beaufort (NMB). En recourant à la méthode de lissage par noyaux, on a calculé les probabilités relatives de présence des membres individuels de chaque population dans chacune des mailles de notre grille. On a évalué l'incertitude dans les probabilités par la méthode de bootstrapping. La disponibilité d'ours polaires au sein de chacune des populations variait géographiquement. Près de Barrow en Alaska, $50 \%$ des ours prélevés viennent de la population MT, et $50 \%$, de la population SMB. Près de $99 \%$ des ours abattus par les chasseurs de Kaktovik proviennent de la SMB. À Tuktoyaktuk, dans les Territoires du Nord-Ouest au Canada, $50 \%$ des prises proviennent de la population SMB et $50 \%$ de celle de la NMB. On a représenté la présence des ours de chaque population sous la forme de probabilités pour chaque maille de notre grille et sous celle de cartes avec courbes de niveau délimitant les changements dans la probabilité relative. Cette nouvelle approche analytique va grandement améliorer la justesse de l'attribution des quotas de prélèvement parmi les communautés de chasseurs et les territoires dont ils relèvent, tout en garantissant que les prélèvements restent dans les limites d'un rendement durable.

Mots clés: Arctique, mer de Beaufort, limites, groupage, attribution de prélèvement, noyau, gestion, ours polaires, Ursus maritimus, démarcation des populations, télémesure, lissage

Traduit pour la revue Arctic par Nésida Loyer.

\footnotetext{
${ }^{1}$ U.S.G.S., Alaska Science Center, 1011 East Tudor Road, Anchorage, Alaska 99503, U.S.A.

${ }^{2}$ Corresponding author: steven_amstrup@usgs.gov

${ }^{3}$ Canadian Wildlife Service, 5320122 Street, Edmonton, Alberta T6H 3S5, Canada

${ }^{4}$ Western Ecosystems Technology, Inc., 2003 Central Avenue, Cheyenne, Wyoming 82001, U.S.A.
} 


\section{INTRODUCTION}

Radio-collared polar bears have been shown to travel from the Canadian portion of the Beaufort Sea into the eastern Chukchi Sea of Alaska (Amstrup et al., 1986, 2000; Amstrup and DeMaster, 1988; Amstrup, 1995, 2003). Recognition that these animals are shared by Canada and Alaska prompted development of the Polar Bear Management Agreement for the Southern Beaufort Sea. This "Agreement" between the Inupiat hunters of Alaska and the Inuvialuit hunters of Canada was ratified by both parties in 1988 (Treseder and Carpenter, 1989; Nageak et al., 1991). The text of the Agreement included provisions to protect bears in dens and females with cubs. The Agreement also stated that the annual sustainable harvest from the southern Beaufort Sea (SBS) polar bear population would be shared equally between the two jurisdictions; that harvests were to be reviewed annually in light of the best current scientific information; and that, if necessary, quotas would be adjusted (Brower et al., 2002).

A principal assumption of the Agreement was that polar bears harvested between about Pearce Point, Northwest Territories (NWT), Canada, and Icy Cape, Alaska, came from the same SBS population. That conclusion was based upon analyses of radiotelemetry data collected between 1981 and 1988 (when the Agreement was signed) and mark-recapture data collected from 1971 through 1988 (Amstrup et al., 1986; Amstrup and DeMaster, 1988; Stirling, 2002).

Capture-recapture and radiotelemetry data have confirmed that, although individual bears typically remain within the SBS region, bears from this region sometimes move into areas occupied by adjoining populations. This phenomenon produces extensive population overlap in the eastern and western portions of the SBS. Identified boundaries are useful as general descriptors of particular stocks. Boundaries designated by lines on maps are inadequate for managing the harvest or assessing the consequences of other human perturbations, however, because by themselves, they cannot account for movements of individual bears across the boundaries of adjacent populations. In this paper, we combine newly developed analytical procedures (Amstrup et al., 2004) with a more extensive radiotelemetry data set than has previously been available, to quantify the overlap probabilities among bears from different groups occupying the SBS region, and to estimate the degree of uncertainty in those probabilities. The SBS and other population boundaries used are those adopted by the International Union for the Conservation of Nature and Natural Resources (IUCN) Polar Bear Specialist Group (PBSG), which are recognized worldwide (Lunn et al., 2002). Figure 1 illustrates boundaries of the three stocks previously identified in the region of the Beaufort Sea of Alaska and Canada. By quantifying the geographic overlap among bears comprising these previously designated populations, we show how to allocate polar bear harvests more accurately among the communities and jurisdictions, thereby improving the efficacy of the Agreement.
METHODS

\section{Field Procedures}

Our study area included the Chukchi Sea adjacent to northwestern Alaska and the Beaufort Sea of northern Alaska and northwestern Canada (Fig. 1). We captured, marked, and radio-collared polar bears in coastal portions of this area each spring between 1985 and 2003 (except 1995 ) and each autumn of 1985, 1986, 1988, 1989, 1994, and 1997-2001. Autumn captures occurred in October and November, and spring captures occurred between March and May. Also included in our analyses were data collected by Bethke et al. (1996) from eight polar bears that comprised their "northern Beaufort Sea" polar bear population.

We live-captured adult female polar bears to attach satellite radio collars by injecting Telazol ${ }^{\circledR}$ (tiletamine hydrochloride plus zolazepam hydrochloride, Fort Dodge Animal Health, Fort Dodge, Iowa) with projectile syringes fired from helicopters (Larsen, 1971; Schweinsburg et al., 1982; Stirling et al., 1989). Collars used in this study were ultra-high frequency (UHF) platform transmitter terminals (PTTs) that were relocated by satellite. We did not radio-collar male polar bears because their necks are larger than their heads, and they do not retain radio collars.

Although some PTTs transmitted daily, most used an energy-saving duty cycle in which they transmitted for short periods (e.g., 4-8 hours) and were dormant for longer periods (e.g., 3-7 days). Collars carrying PTTs also carried VHF beacons that we located from aircraft (Amstrup and Gardner, 1994). Data retrieved from PTTs were processed by the Argos Data Collection and Location System (ADCLS; Fancy et al., 1988).

\section{Data Analysis}

Whereas traditional analyses of radiotelemetry data provide a retrospective description of where instrumented animals were relocated during a study, our objective was to analyze radiotelemetry data to define population boundaries in ways that make them more relevant to harvest quota allocation and other management challenges. To do that, we needed to be able to identify individuals belonging to three identified populations and to quantify the occurrence probability for all individuals at every location in our study area.

The methodology we applied in this paper is described in detail in Amstrup et al. (2004). Here we briefly summarize the seven steps used in our analytical procedures. First, we standardized PTT transmissions so that variations in duty cycles among transmitters and variations in signal strengths among duty cycles did not bias data inputs. We deleted all observations for which the reported location may not have been within $1000 \mathrm{~m}$ of the true location of the animal (i.e., those that did not fall into ARGOS class 1, 2, or 3, cf. Harris et al., 1990). We then 


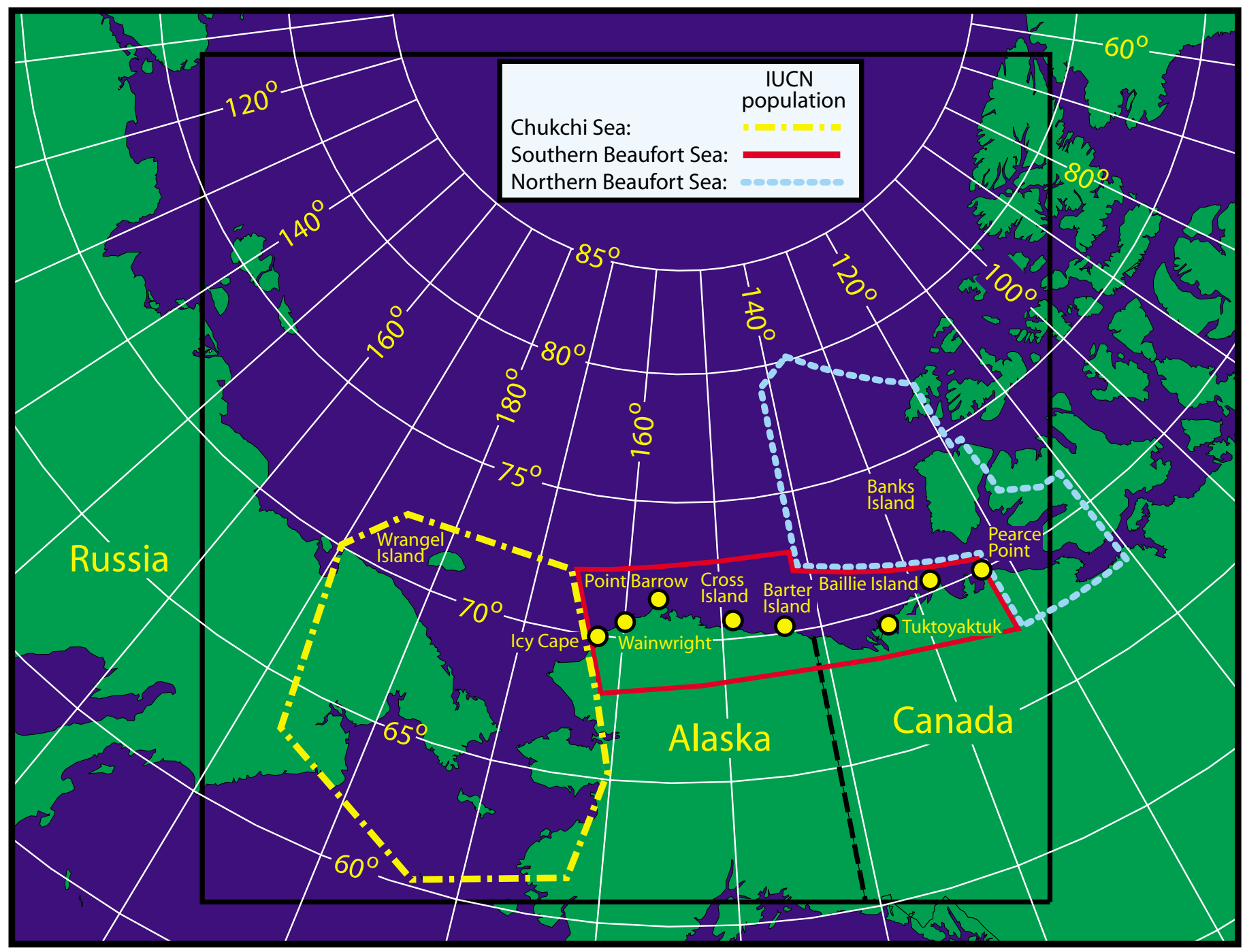

FIG. 1. Approximate boundaries of the grid (large square) used to smooth polar bear distributions and to estimate occurrence probabilities of polar bears in the southern Beaufort Sea and adjacent areas. Also shown are boundaries of three polar bear populations recognized by the International Union for the Conservation of Nature and Natural Resources (IUCN) (Lunn et al., 2002), and place names used in text.

deleted all but the one with the highest-quality index in each duty cycle. Duty cycles of deployed PTTs varied among years. We standardized duty cycles by excluding locations recorded more frequently than every six days. We also deleted animals from our analyses if their reobservation histories did not cover a whole year or if they included data gaps of 60 days or longer.

Second, we established a prediction grid of 660 square cells ( $5 \mathrm{~km}$ on each side) over our study area, from west of Wrangel Island (Russia) east to Banks Island (Canada) and from near the North Pole southward into the Bering Sea. Boundaries of this grid, which extended from $56^{\circ} \mathrm{N}$ to $80^{\circ}$ $\mathrm{N}$ and from $112^{\circ} \mathrm{W}$ to $170^{\circ} \mathrm{E}$, are shown in Figure 1 .

Third, we developed a two-dimensional Gaussian kernel density estimator to calculate home ranges for each instrumented bear. We used a true 2-D approach that allowed the major and minor axes of our density estimator or "smoother" to differ in length (bandwidth) and orientation (Amstrup et al., 2004). "Smoothing" converted actual radiolocations within our grid to the estimated probability that an individual bear would occur in each cell of our grid.

Fourth, we grouped individual bears according to the degree to which their home ranges were shared. Clustering (Johnson and Wichern, 1988; Norusis, 1994) bears according to their distribution density values in each cell in our grid allowed us to determine whether bears radiocollared in the SBS region fell into distinct groups. Previously, polar bear clustering has been based on centroids calculated from the distribution of their relocations collected over designated periods. Boiling dozens of relocations down to one "representative" point (Bethke et al., 1996; Taylor et al., 2001) sacrifices the information in those relocations and in the probability surfaces generated from them. Therefore, we clustered bears by the degree to which the areas they occupied overlapped. To do this, we scaled kernel density estimates for each cell for each bear (step 3) so that they summed (integrated) to 1. Scaling in this way converted absolute intensity-of-use values for 
each bear in each grid cell into proportional use values. This conversion assured that bears for which there were few observations would be represented by the same amount of information as bears from which more observations were available. This step was critical because some bears generated more locations than other bears.

Because vectors formed from our grid of $5 \mathrm{~km} \times 5 \mathrm{~km}$ cells $(660 \times 660=435600$ cell entries $)$ were too large for SAS Proc Cluster (SAS Institute, 1999) to handle, we overlaid our $5 \mathrm{~km}$ grid with a grid of cells $100 \mathrm{~km}$ on each side and summed the probability values for all of the 400 smaller cells in each of the larger cells. The second grid was $33 \times 33$ or a total of 1089 cells. SAS was able to cluster the resulting matrix of 194 (bears) $\times 1089$ (cells). We used Ward's clustering algorithm, which is robust to minor differences between cluster members and tends to emphasize major differences (e.g., population membership) among clusters more effectively than other methods (Norusis, 1994). We measured distances between clusters, as they were amalgamated, with the semi-partial $R^{2}$ values reported by Proc Cluster of SAS.

Our fifth step, after defining populations by clustering, was to calculate the distributions of those populations. We combined the relocations of all members of each population and calculated the total number of relocations in each cell of our original $5 \mathrm{~km}$ grid. We calculated population ranges, as we did for individual bears (step 3 above), by smoothing and scaling the raw frequencies of locations in each population with a 2-D Gaussian kernel density estimator with fixed elliptical bandwidth.

In our sixth step, we calculated the relative probability that a member of each population would occur in each cell of our grid. To do this, kernel density estimates for each cell for each population (step 5) were scaled so that they summed (integrated) to 1 . As with the scaling of individual bears (step 4), this scaling removed the influence of unequal numbers of radio relocations in the three different populations.

To calculate relative probability of occurrence of bears from each population in each grid cell, we required an estimate of the size of each population. Scaled density estimates told us the estimated "proportion" of each population occurring in each cell of our grid. Multiplying those proportions or fractions by the estimated size of each population yielded expected numbers of bears from each population in each grid cell. Because our clustering procedure identified SBS, CS, and NBS populations (see Results), we felt comfortable incorporating into our procedure the size estimates for groups of the same names given by Lunn et al. (2002). Population sizes listed in Table 1 of that report were 2000 for the Chukchi Sea (CS) population, 1200 for the northern Beaufort Sea (NBS) population, and 1800 for the southern Beaufort Sea (SBS) population. Because these IUCN-accepted estimates were not associated with specific time frames, and because no estimates of variance were available, we held them constant in our analysis for all years from which we had data.
Population estimates were used only to convert scaled probability densities to estimates of the relative numbers of bears in each cell. The important aspect of these estimates is not the absolute population levels, but rather that the ratios of one population size to another were sensible, and that estimates for each population were of comparable quality. Also implicit in our computations is the assumption that uncollared bears move and use space similarly to collared bears. Justification for this assumption was that we were aware of no reason why behavior of unmarked females in any of the populations would be fundamentally different from that of collared females. In addition, available evidence suggests little or no difference in movement patterns and space use between male and female polar bears throughout most of the study area (Stirling et al., 1980, 1984; Schweinsburg et al., 1981; Lentfer, 1983; Amstrup et al., 2001a).

We calculated the relative probability that a bear sighted in a particular cell was a member of population $i$, as:

$$
p_{i}=\frac{a_{i} \hat{N}_{i}}{\sum_{j=1}^{k} a_{j} \hat{N}_{j}},
$$

where $a_{i}$ was the scaled kernel density estimate of the probability that a bear from population $i$ was located in the cell (the fraction of population $i$ in that cell), $\hat{N}_{i}$ was the estimated size of population $i$, and $k$ was the number of populations. This formula provides the relative probability $\left(p_{i}\right)$ that a bear sighted in any cell belongs to each population.

In our final analytical step, we calculated interval estimates on relative probability values by bootstrapping. A limitation in all previous analyses of radiotelemetry data is that they have not incorporated estimates of uncertainty (White and Garrott, 1990; Kenward, 2001). Bootstrapping allowed us to derive those estimated levels of uncertainty and, for the first time ever, to apply confidence intervals to our probability point estimates. To achieve the speed necessary to bootstrap an estimate of precision for our relative probability values, we used the method of Kern et al. (2003).

Polar bears in Alaska and Canada are harvested in a seasonal pattern. Along the SBS coast, they are taken frequently in autumn and early winter and again in late winter and spring. Along the CS coast south of Barrow, they are taken almost exclusively in late winter and spring because sea ice for hunting does not persist along the coast until then (Schliebe et al., 1995; Brower et al., 2002). Therefore, we calculated the relative probabilities $\left(p_{i}\right)$ and associated standard errors for each cell on an annual (yearround) basis and for the two seasons during which bears are most frequently hunted. We defined fall as SeptemberJanuary and spring as February-May. To evaluate management ramifications of observed differences between the annual and seasonal $p_{i}$ for the fall and spring seasons, we explored spatial patterns in $p_{i}$ from different populations 
for each season. Polar bears are infrequently taken during the summer months (Schliebe et al., 1995; Brower et al., 2002), so we did not calculate separate $p_{i}$ for June-August. We tested for differences between annual and seasonal $p_{i}$ by deriving individual test statistics that are similar to a Student's t-test for each cell in the grid:

$$
\left(t^{*}=\frac{p_{a}-p_{s}}{\sqrt{s_{a}^{2}+s_{s}^{2}}}\right)
$$

The numerator in this statistic is simply the difference between the annual and seasonal $p_{i}$ of interest, and the denominator is the square root of the sum of the squares of the standard errors associated with each $p_{i}$ (Zar, 1984:131). We refer to this as a " $t$-like" statistic because sample sizes and degrees of freedom that apply to our calculations of relative probabilities $\left(p_{i}\right)$ are not easily derived. Similarly, it is not clear how to assess the degree of independence or lack of same among individual cell $p_{i}$. Nonetheless, this $t^{*}$ statistic does provide the ability to judge whether differences between seasonal and annual $p_{i}$ are large or small relative to their estimated standard errors. Even without knowing the appropriate degrees of freedom etc., we know that if differences are large and standard errors are large, values of $t^{*}$ will be small. Similarly, if differences are small and standard errors are small, the values of $t^{*}$ will also be small. Values of $t^{*}$ can be large only when differences between $p_{i}$ are large and standard errors are small, just as in the standard $t$-test. We considered differences between seasonal and annual $p_{i}$ to be "large" for grid cells in which these values exceeded 1.96. This value corresponds to the difference that would be significant at approximately a 0.05 level when testing differences between two normally distributed means (Zar, 1984; Scheaffer et al., 1986).

\section{RESULTS}

We collected 412640 satellite observations from 387 polar bears between 1985 and 2003. After filtering and standardizing, we used 15308 of those observations from 194 polar bears collared between 1985 and 2003 to delineate polar bear populations and estimate encounter probabilities. Figure 2 illustrates capture locations for these bears, and Figure 3 is a 5\% sample of the radiolocations of bears representing each population.

\section{Population Identification}

We halted the clustering program when it reached the first logical step that was obviously larger than previous steps. The combination of increasingly dissimilar clusters of polar bears resulted in a gradual increase in step size until the point where three clusters were amalgamated into two. That step was much larger than we had seen previously, and it indicated our telemetry data fell into three relatively discrete groups occurring within our study area.
Hereafter, we refer to these clusters or groups as populations, although we recognize they cannot be distinguished on genetic bases alone (Cronin et al., 1991; Paetkau et al., 1999).

\section{Population Distributions and Relative Probabilities of Occurrence}

From west to east, the three populations identified by our clustering were CS, SBS, and NBS. We used 6151 satellite relocations from 92 PTT-equipped bears that clustered into the CS population. We also used 6410 locations from 71 SBS bears and 2747 locations from 31 NBS bears.

Kernel smoothing of bear locations provided estimates of the proportion of time bears from each population spend in each grid cell. Those probability values allowed distributions of each population to be illustrated by $50 \%$ and 95\% kernel estimates of the intensity with which bears from each population used different portions of the study area (Fig. 4). Ratios of these "intensity of use" values provided the relative probabilities $\left(p_{i}\right)$ of sighting or harvesting a bear from each of our three populations in each cell of our grid. These probabilities varied greatly across the study area.

At the most detailed level, our data are presented as values for each cell in our grid. Figure 5 shows these cell values, calculated from year-round data, near four selected communities and known hunting locations in the region. There were no large differences between annual relative probabilities and either autumn or spring harvest probabilities for those hunting locales. In fact, large differences between seasonal and annual probabilities were found only in small offshore areas where human activities are currently absent (Amstrup et al., 2004). In other words, although the number of bears available along the coast varies from season to season, the proportional composition of those bears does not. This finding means that, within our study area, managers do not need to consider the season in which a bear was harvested when they do their allocations.

On a larger scale, grid cells with similar values can be connected to form contours of occurrence probability. Each of these contour lines connects grid cells of comparable harvest probability. Figure 6 illustrates the relationship between probability of occurrence contours and current population boundaries. Contour lines show that harvests in coastal areas of Alaska between Wainwright and Barrow are approximately $30-40 \%$ SBS bears, and the rest are CS bears. At Barrow, half of the bears observed or harvested are from the SBS and half from the CS. Around Prudhoe Bay and the village of Kaktovik, Alaska, nearly all bears harvested are from the SBS population (Figs. 5, 6). Between the village of Kaktovik on Barter Island and Tuktoyaktuk, the probability of harvesting NBS bears increases to about $50 \%$. North and east of the Tuktoyaktuk Peninsula, over $90 \%$ of the bears harvested are from the 


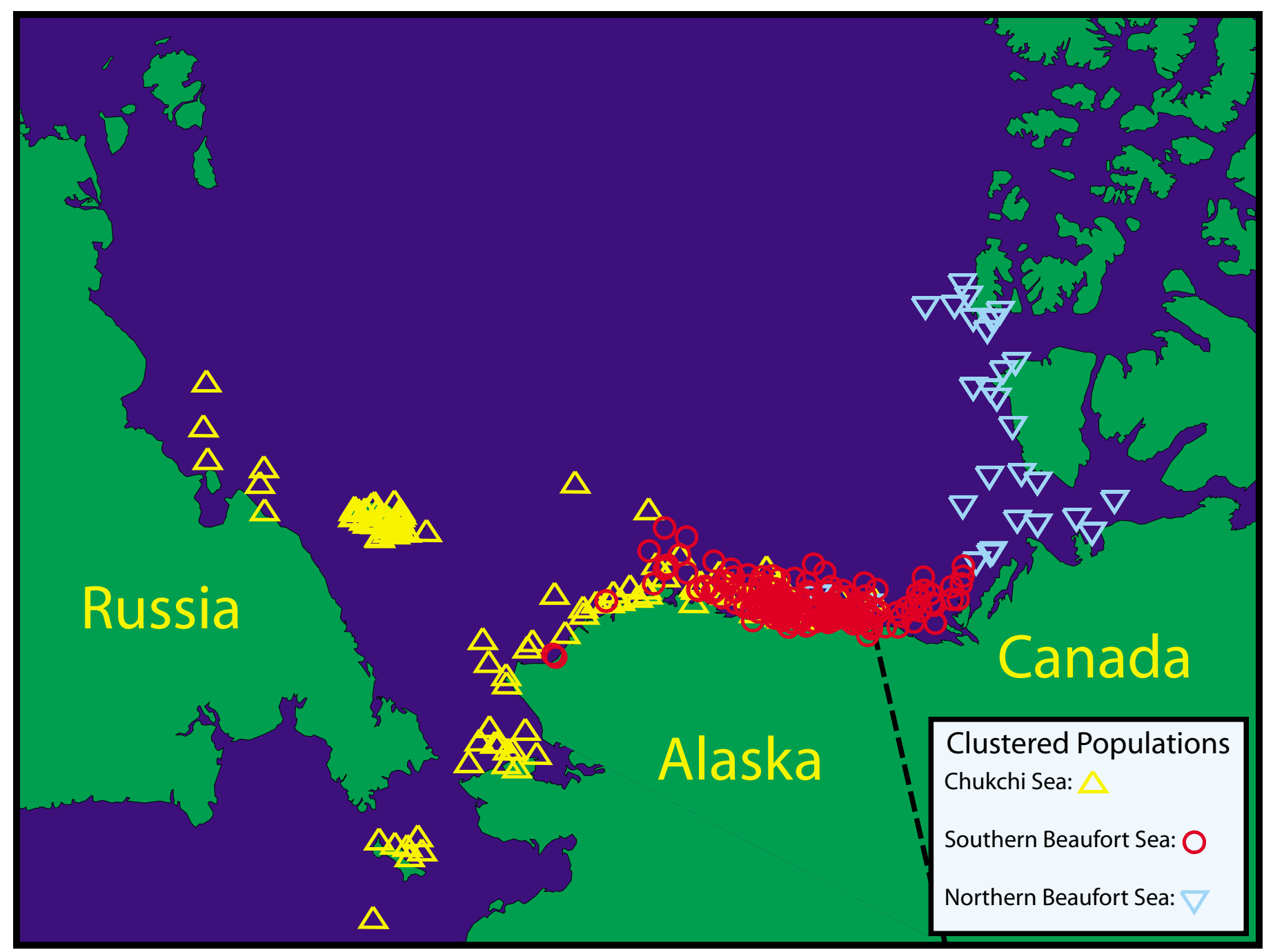

FIG. 2. Approximate capture locations of polar bears followed by satellite radiotelemetry in the southern Beaufort Sea region between 1985 and 2003 . The symbol for each bear represents the population into which it was clustered.

NBS group (Figs. 5, 6). We expressed the uncertainty in our estimated probability values as coefficients of variation (CVs) (Zar, 1984). CVs for harvest probability estimates were small across most of our study area, lending credence to these estimated probabilities (Fig. 6).

\section{DISCUSSION}

Although individual polar bears appear to be largely independent of each other in their movements, clustering algorithms based on the distribution of data demonstrate similarities in those movement patterns. Those similarities define groups of polar bears that from a management standpoint can be treated as populations. By smoothing radiotelemetry observations, we can estimate the probability of encountering a polar bear at any geographic location. Estimated probabilities combined with bootstrapped estimates of error allow us to make probabilistic statements about the population of bears to which any individual belongs. Current conservation and management are based on the presumption that the polar bears are distributed in 21 stocks or subpopulations worldwide (Lunn et al., 2002). These identified stocks differ greatly in the degree to which genetic differences correspond with the mapped boundaries (Paetkau et al., 1999), but in all cases, the distributions of individual bears from adjacent areas are known to overlap geographically. Terms such as group, stock, population, etc., simplify communications and jurisdictional issues. Such terms, however, are most useful for management purposes if they can be linked to probabilistic descriptions of those geographic overlaps. Our method provides that link (Amstrup et al., 2004).

The relative probability that members of each population occur in each cell of our grid varied significantly across the region covered by the Agreement. Small standard errors (recall that we converted estimates of uncertainty from standard errors to coefficients of variation) increase confidence in our ability to assess the probability that a polar bear harvested between Barrow and the Baillie Islands originated from a particular population. In all areas where polar bears are currently hunted, differences between seasonal and annual 


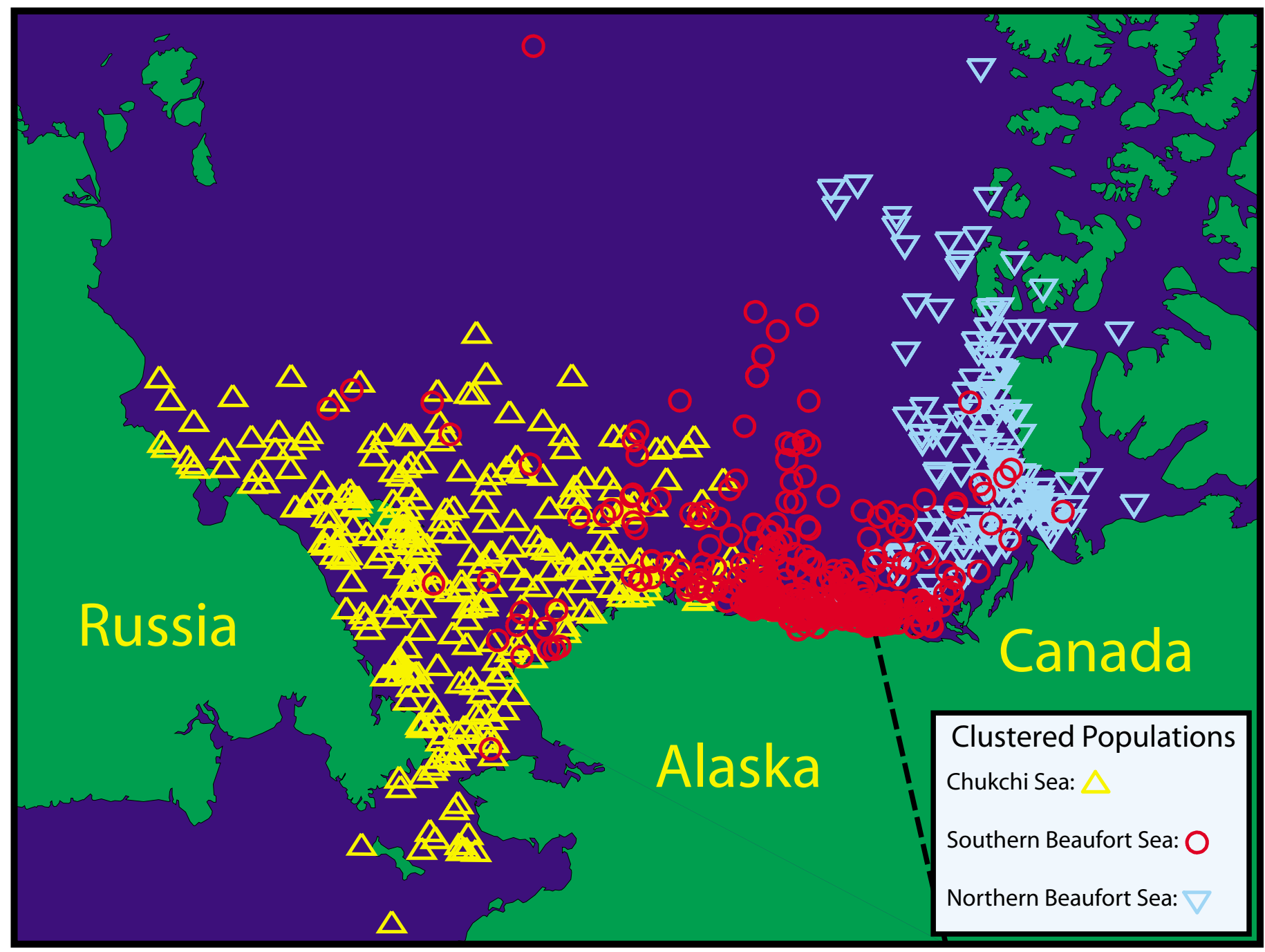

FIG. 3. A random sample (5\% of locations) of the 15308 polar bear re-observation sites recorded by satellite radiotelemetry between 1985 and 2003 and used in this study.

relative probabilities were too small to have statistical or practical significance. For harvest allocation, therefore, we can apply probabilities generated from year-round data to the distribution of the harvest for hunters from each community. This maximizes the sample sizes available and hence the precision of estimates.

We used population estimates for our three populations to convert scaled probability densities to estimates of the relative numbers of bears from each population in each cell. The ratios of one population size to another needed to be sensible and of comparable quality so as not to bias probabilities of occurrence in each cell in favor of one population or another. The most accurate harvest allocation numbers, however, will require that size estimates for each population be accurate and of comparable quality. The procedure outlined here allows better population estimates to be incorporated seamlessly into the estimation process as new data become available. It also provides a mechanism to improve those population estimates.

The low densities at which polar bears occur and their relative invisibility against a background of white snow and ice have made capture-recapture the most common procedure used to estimate population size (Lunn et al., 1997; Stirling et al., 1999; Amstrup et al., 2001b; McDonald and Amstrup, 2001). Just as the Agreement was based upon the assumption that hunters share one population throughout the SBS, early population estimates were based upon the same assumption. Therefore, the inability to appreciate overlap among members of adjacent populations has restricted the accuracy of past population estimates in the Beaufort Sea and elsewhere (Amstrup et al., 2001b).

Capture-recapture estimation models for open populations are based on the ratios of new captures to recaptures during recurring occasions. Modern models provide an estimate of the probability of capture for each bear captured on each occasion (different years in our case). To derive an estimate of population size, we invert (take the reciprocal of) the estimated capture probability for each captured animal. The sum of all of the inverted capture probabilities on each capture occasion becomes the population estimate for that occasion. So if an animal is estimated to have a capture probability of 0.10 (or a $10 \%$ 


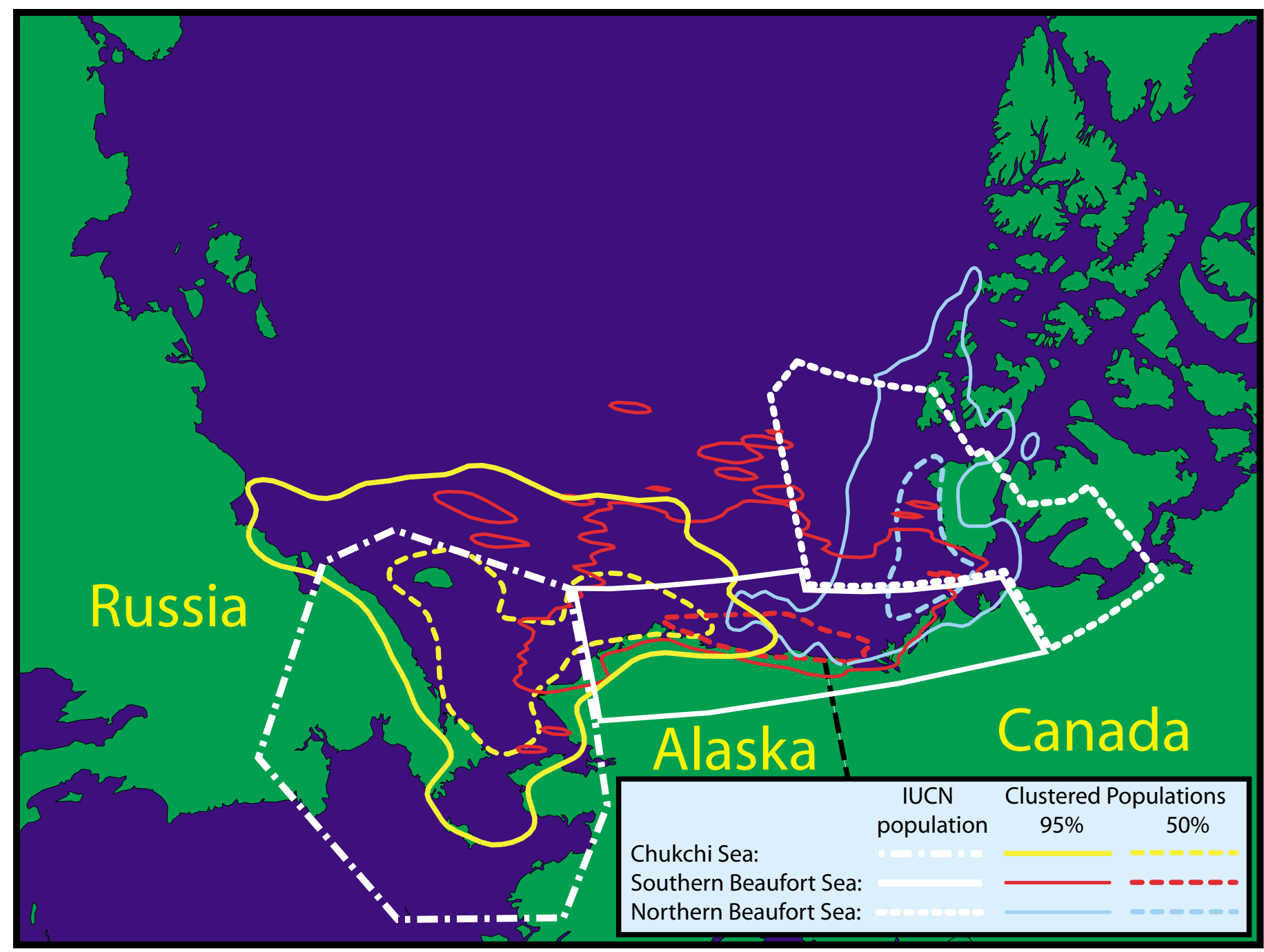

FIG. 4. Intensity of use or boundary contours (50\% and $95 \%$ ) for three polar bear populations occupying the Beaufort Sea region. Populations were identified by clustering satellite radiotelemetry locations (see Fig. 3) using Ward's agglomeration schedule (Norusis, 1994) and applying a 2-D kernel smoother to identify population boundary contours. Also shown are the boundaries previously identified by IUCN for the same populations (Lunn et al., 2002).

chance of being captured on that occasion), the reciprocal of that capture probability is 10 . In other words, the capture of that animal is worth 10 bears to our population estimate for that occasion. By adding the reciprocals of capture probabilities for all bears captured on each occasion, we produce the estimate of the number of animals in the population. If we captured 100 animals, each with the same 0.10 capture probability, our population estimate for that capture occasion would be 1000 animals.

In the past, we did not know whether a captured bear represented the population we were trying to estimate or not. The method described here, however, provides the relative probability of catching a bear from any of our study populations at any geographic location, as well as an estimate of the error or uncertainty in that probability estimate. Multiplying each inverted capture probability by the relative probability of occurrence tells us what fraction of each captured bear applies to our target population. For example, without our estimate of probability of occurrence, the bear mentioned above is worth 10 bears to the population estimate regardless of where it is captured. Now we know, however, that if we are estimating the size of the SBS population, that bear is worth 10 bears only if it is captured in the central part of the Beaufort Sea. If that same bear were to be captured near Barrow, where SBS bears have a probability of occurrence of 0.5 , it would still be worth a total of 10 to the "super population" that includes CS, SBS, and NBS animals, but it would contribute only five bears to the SBS estimate. The rest of that bear's value, in terms of population size, would belong to the CS population (near Barrow, there is almost no probability of occurrence for NBS bears). In this way, the method described in this paper allows us to refine not only the allocation of harvests, but also the population size estimates and hence the size of the harvests permissible.

The assumption that hunters from all communities covered by the Agreement are equally likely to harvest bears from the SBS population is not supported by these analyses. The current annual harvest quota of 82 polar bears for the SBS is based on the assumption that all bears taken between 

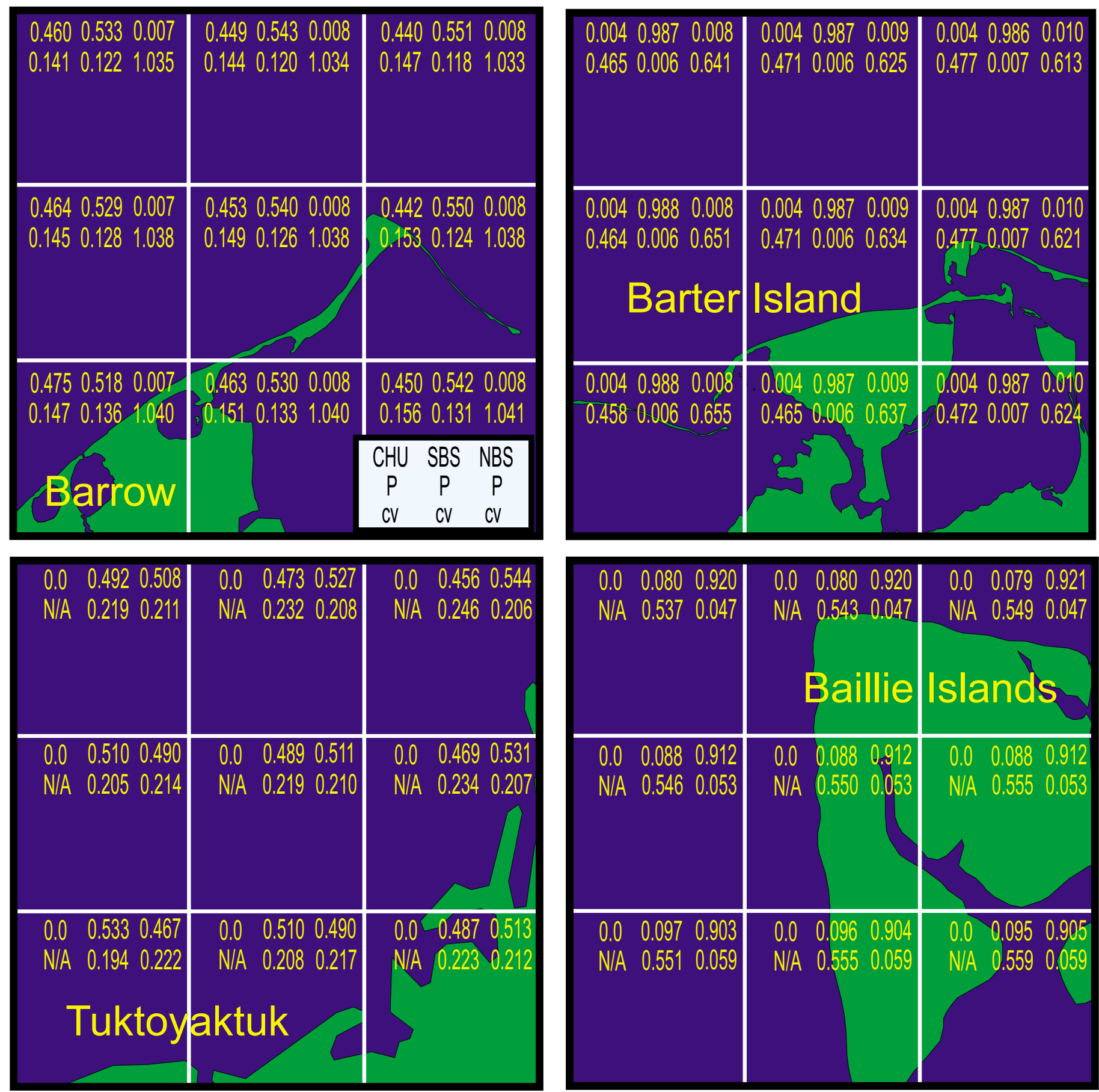

FIG. 5. Estimated year-round probabilities $\left(p_{i}\right)$ of harvesting a polar bear from each of three populations in individual grid cells near Barrow and Barter Island, Alaska, and Tuktoyaktuk and Baillie Islands, Canada. Also shown are the coefficients of variation of the $p_{i}$, which are calculated by bootstrapping.

Wainwright, Alaska, and Pearce Point, Northwest Territories, belong to the SBS population. Clearly this paradigm is not supported by the most recent quantitative data. Hence, harvest management for polar bears in the Chukchi and Beaufort seas can no longer be based on the previously established population boundaries (Fig. 1). To be most effective, future management will need to apply the manager's knowledge of where hunters from each community harvest their bears, estimates of population size, and the probabilities of encountering bears from each population throughout the area. Harvests could be assigned grid cell by grid cell (using the $25 \mathrm{~km}^{2}$ grid that we superimposed over the study area) to assure maximum resolution and accuracy of allocation. The distribution of quotas would be based on the harvest distribution as projected from past harvest reports. After each hunting season, managers could allocate the harvested bears to the appropriate populations on the basis of reported kill locations. Comparing the actual allocation to that projected would allow managers to adjust the quotas for the next year easily and effectively. Such adjustments also would be more 

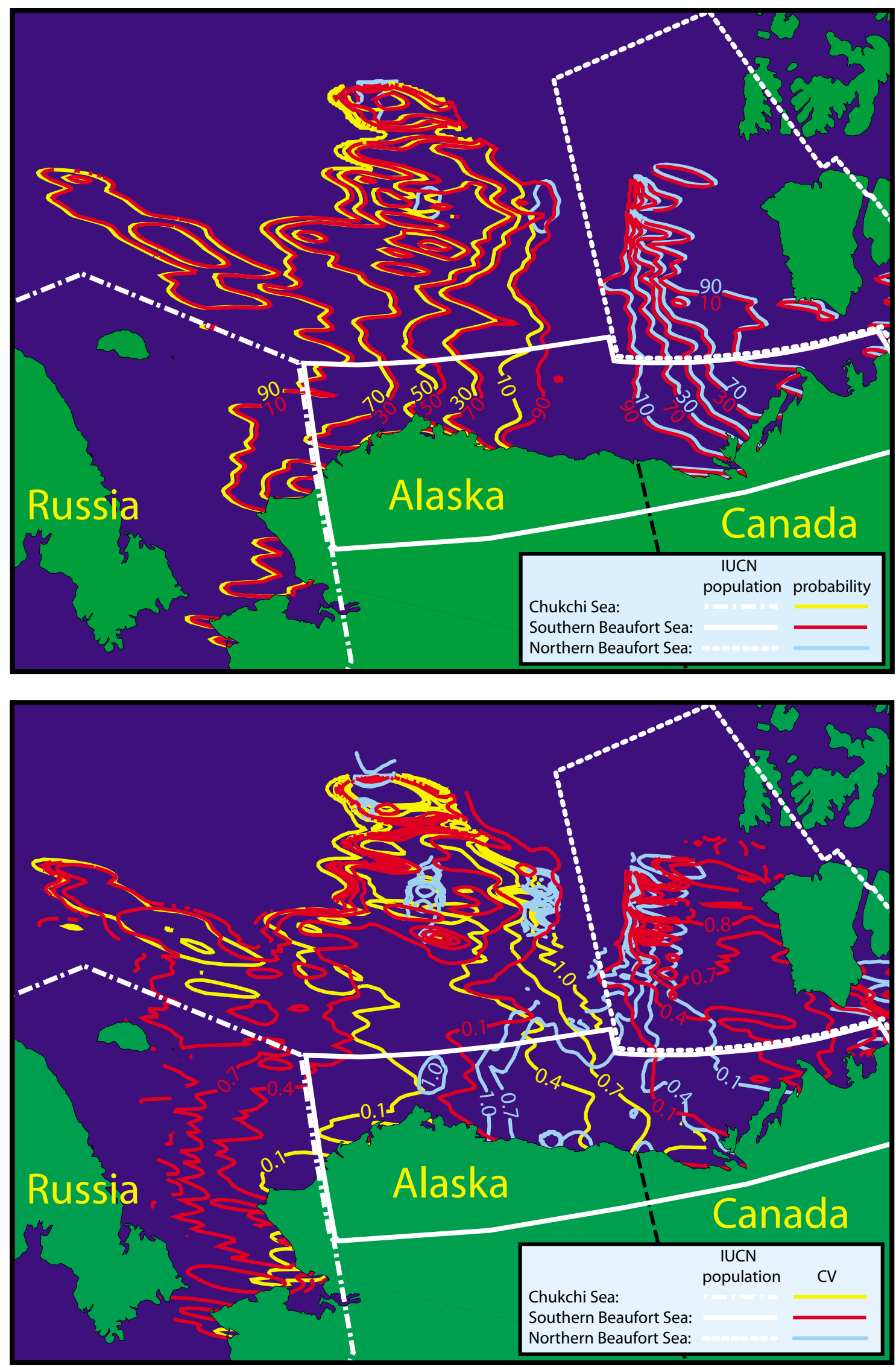

FIG. 6. Contours of the $p_{i}$ or relative probability of occurrence (top) and coefficient of variation (CV) on the $p_{i}$ values (bottom) for members of the three populations of polar bears in the Beaufort Sea region identified using radiotelemetry data. 


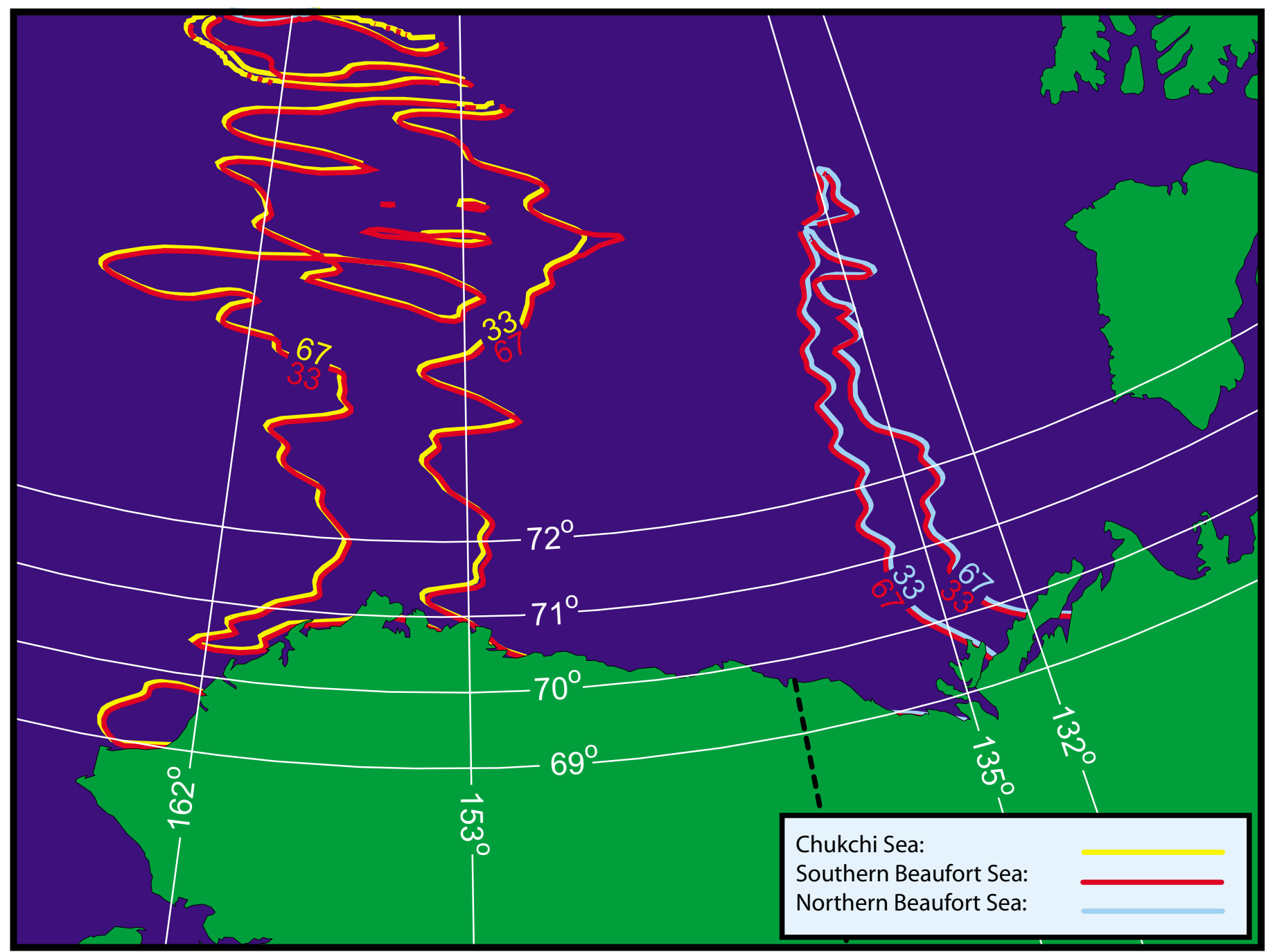

FIG. 7. Hypothetical example of subunit boundaries for polar bear hunting in the southern Beaufort Sea. In this model, all bears taken between $135^{\circ}$ and $153^{\circ} \mathrm{W}$ longitude would be classified as SBS polar bears and allocated to the SBS harvest quota. Only half of the bears taken between $132^{\circ}$ and $135^{\circ} \mathrm{W}$ and between $153^{\circ}$ and $162^{\circ} \mathrm{W}$ would be allocated to the SBS harvest quota. Bears taken east of $132^{\circ}$ and west of $162^{\circ}$ would not be included in the SBS take.

biologically justifiable than was possible in the past. However, to maximize the benefit of this system of quota allocation, hunters would have to report the kill locations accurately enough to place each one in the correct geographical grid cell. Such fine-scale plotting would be possible if all hunters were to navigate by global positioning systems; however, management at that scale might be difficult during initial implementation, while people are adjusting to a new system. It also might seem unduly complicated at first in comparison to the current system.

Basing management decisions on larger blocks of habitat could make them more workable, although this would be less precise than allocating harvest on a cell-by-cell basis. Managing on larger probability blocks could be accomplished by choosing boundaries along contours of relative probability that correspond to locations where hunters from each settlement frequently take polar bears. Management subunit boundaries extending along both sides of those contours could then be designated. For example, population boundaries in the SBS region could be divided into hunting subunits based on the $50 \%$ contour of the $p_{i}$ for each population (Fig. 7). At Barrow, one of the major polar bear hunting regions in Alaska, $50 \%$ of the bears taken are from the SBS and 50\% from the CS populations. A " $50 \%$ management subunit" (within which half of the bears taken would be assigned to the CS and half to the SBS) then could be established between approximately $162^{\circ} \mathrm{W}$ longitude (where the $67 \% \mathrm{CS}$ contour and the $33 \%$ SBS contours intersect the coast) and $153^{\circ} \mathrm{W}$ longitude (where the 67\% SBS and 33\% CS contours intersect the coast). The village of Tuktoyaktuk, Northwest Territories, also sits right on the $50 \%$ contour line. Because the gradient between the NBS and SBS populations is much steeper than that between the CS and SBS, a similar "management subunit" centered on the eastern $50 \%$ contour for SBS bears would extend only between $135^{\circ}$ and $132^{\circ} \mathrm{W}$ longitude.

Continuing with the hypothetical example above, the area between $153^{\circ}$ and $135^{\circ} \mathrm{W}$ longitude could be called SBS Subunit A. Within that section of coast, all bears taken could 
be allocated to the SBS quota. Subunit B could be the region centered on Barrow. Half of the bears taken in that region could be assigned to the SBS and half to the CS. Similarly, in Subunit C, the area surrounding Tuktoyaktuk, half of the harvest could be allocated to the SBS population and half to the NBS population. All bears harvested north and east of $132^{\circ}$ could be assigned to the NBS population, and all harvested west of $162^{\circ} \mathrm{W}$, to the CS.

Adopting the probabilistic approach to management outlined here would require managers and user groups to review the locations of recent harvests and determine the numbers of bears historically killed in each SBS subunit. Those numbers would be used to set the first subunit quotas, as well as to adjust quotas in adjacent population units. The degree to which actual current harvests are aligned with past quotas could be used to adjust future quotas for each subunit until the desired match is achieved.

In practice, actual management subunit boundaries should be selected in ways that aid managers and users to embrace this new approach to harvest allocation. Therefore, "real" center and end points of subunits would likely differ from the above example. Any system of subunits would be a compromise between the old management paradigm and our new probabilistic approach. Accuracy of harvest allocation would also be a compromise. With experience, however, harvest zones, whatever their initial boundaries, could become smaller and more refined, so that over time, allocations would asymptotically approach small aggregates of cells or individual cell values.

As required by the Agreement between the Inuvialuit and the Inupiat hunters (Treseder and Carpenter, 1989; Nageak et al., 1991; Brower et al., 2002), the methods described in this paper use the latest available knowledge to achieve polar bear conservation. Because new data can be seamlessly incorporated at any time they are collected, these methods assure that polar bear harvests in this region will always benefit, as the Agreement requires, from the latest knowledge available. Our results confirm that harvests at the eastern and western ends of the area specified in the Agreement should be allocated to the SBS at lower levels than is currently the case. These results also confirm that harvest quotas in the CS and NBS areas may need to be adjusted. When managers and users become accustomed to managing harvests according to where polar bears live and where harvests occur, rather than simply according to where hunters live or where lines have been drawn on maps, allocation of harvests will be more intuitive, as well as more biologically relevant. Intuitive and biologically based management is more likely than the previous subjective approaches to assure sustainable harvests from the populations of polar bears in this region.

\section{ACKNOWLEDGEMENTS}

Principal funding was provided by the Biological Resources Division, U.S. Geological Survey. Other major contributors were
BP Exploration Alaska, Inc.; the National Oceanic and Atmospheric Administration, U.S. Department of Commerce; ARCO Alaska, Inc.; the Minerals Management Service, U.S. Department of the Interior; the Polar Continental Shelf Project, Department of Resources, Wildlife, and Economic Development of the Northwest Territories; the Inuvialuit Game Council; and the Canadian Wildlife Service. We are grateful to D. Douglas for aid in acquisition and organization of satellite data. We thank D. Andriashek, M. Branigan, A.E. Derocher, and N. Lunn for assistance in the field and K. Simac for editorial suggestions. This manuscript includes analyses of data collected in Russia and western Alaska by G.W. Garner (deceased). We thank M.K. Taylor and F. Messier for permission to include their radiolocation data from the northern Beaufort Sea in these analyses. Research described could not have been accomplished without the cooperation and support of the Inuvialuit people of northwestern Canada and the Inupiat people of northern Alaska. We are particularly indebted to A. Carpenter of the Inuvialuit Game Council and to C. Brower of the North Slope Borough Wildlife Management Department for their constant support of polar bear research and its use in developing co-management practices around the Beaufort Sea.

\section{REFERENCES}

AMSTRUP, S.C. 1995. Movements, distribution, and population dynamics of polar bears in the Beaufort Sea. Ph.D. dissertation, University of Alaska Fairbanks.

2003. Polar bear. In: Feldhammer, G.A., Thompson, B.C., and Chapman, J.A., eds. Wild mammals of North America: Biology, management, and conservation. 2nd ed. Baltimore, Maryland: Johns Hopkins University Press. 587-610.

AMSTRUP, S.C., and DeMASTER, D.P. 1988. Polar bear: Ursus maritimus. In: Lentfer, J.W., ed. Selected marine mammals of Alaska: Species accounts with research and management recommendations. Washington, D.C.: Marine Mammal Commission. 39-56.

AMSTRUP, S.C., and GARDNER, C. 1994. Polar bear maternity denning in the Beaufort Sea. Journal of Wildlife Management 58(1):1-10.

AMSTRUP, S.C., STIRLING, I., and LENTFER, J.W. 1986. Past and present status of polar bears in Alaska. Wildlife Society Bulletin 14(3):241-254.

AMSTRUP, S.C., DURNER, G., STIRLING, I., LUNN, N.J., and MESSIER, F. 2000. Movements and distribution of polar bears in the Beaufort Sea. Canadian Journal of Zoology 78:948-966.

AMSTRUP, S.C., DURNER, G.M., McDONALD, T.L., MULCAHY, D.M., and GARNER, G.W. 2001a. Comparing movement patterns of satellite-tagged male and female polar bears. Canadian Journal of Zoology 79:2147-2158.

AMSTRUP, S.C., McDONALD, T.L., and STIRLING, I. 2001b. Polar bears in the Beaufort Sea: A 30-year mark-recapture case history. Journal of Agricultural, Biological, and Environmental Statistics 6:221-234.

AMSTRUP, S.C., McDONALD, T.L., and DURNER, G.M. 2004. Using satellite radiotelemetry data to delineate and manage wildlife populations. Wildlife Society Bulletin 32(3):661-679. 
BETHKE, R., TAYLOR, M., AMSTRUP, S., and MESSIER, F. 1996. Population delineation of polar bears using satellite collar data. Ecological Applications 6(1):311-317.

BROWER, C.D., CARPENTER, A., BRANIGAN, M.L., CALVERT, W., EVANS, T., FISCHBACH, A.S., NAGY, J.A., SCHLIEBE, S., and STIRLING, I. 2002. The Polar Bear Management Agreement for the Southern Beaufort Sea: An evaluation of the first ten years of a unique conservation agreement. Arctic 55(4):362-372.

CRONIN, M.A., AMSTRUP, S.C., GARNER, G.W., and VYSE, E.R. 1991. Interspecific and intraspecific mitochondrial DNA variation in North American bears (Ursus). Canadian Journal of Zoology 69:2985-2992.

FANCY, S.G., PANK, L.F., DOUGLAS, D.C., CURBY, C.H., GARNER, G.W., AMSTRUP, S.C., and REGELIN, W.L. 1988. Satellite telemetry: A new tool for wildlife research and management. U.S. Fish and Wildlife Service Resource Publication 172.

HARRIS, R.B., FANCY, S.G., DOUGLAS, D.C., GARNER, G.W., AMSTRUP, S.C., McCABE, T.R., and PANK, L.F. 1990. Tracking wildlife by satellite: Current systems and performance. U.S. Fish and Wildlife Service Technical Report 30.

JOHNSON, R.A., and WICHERN, D.W. 1988. Applied multivariate statistical analyses. 2nd ed. Englewood Cliffs, New Jersey: Prentice Hall.

KENWARD, R.E. 2001. Historical and practical perspectives. In: Millspaugh, J.J., and Marzluff, J.M., eds. Radio tracking and animal populations. London: Academic Press. 3-12.

KERN, J.W., McDONALD, T.L., AMSTRUP, S.C., DURNER, G.M., and ERICKSON, W.P. 2003. Using the bootstrap and fast Fourier transform to estimate confidence intervals of 2-D kernel densities. Environmental and Ecological Statistics 10(4): $405-418$.

LARSEN, T. 1971. Capturing, handling, and marking polar bears in Svalbard. Journal of Wildlife Management 35(1):27-36.

LENTFER, J.W. 1983. Alaskan polar bear movements from mark and recovery. Arctic 36(3):282-288.

LUNN, N.J., STIRLING, I., ANDRIASHEK, D., and KOLENOSKY, G.B. 1997. Re-estimating the size of the polar bear population in western Hudson Bay. Arctic 50(3):234-240.

LUNN, N.J., SCHLIEBE, S., and BORN, E.W., eds. 2002. Polar bears. Proceedings of the Thirteenth Working Meeting of the IUCN/SSC Polar Bear Specialist Group. Occasional Paper of the IUCN Species Survival Commission No. 26. Gland, Switzerland: World Conservation Union.

McDONALD, T.L., and AMSTRUP, S.C. 2001. Estimation of population size using open capture-recapture models. Journal of Agricultural, Biological, and Environmental Statistics 6: 206-220.

NAGEAK, B.P., BROWER, C.D., and SCHLIEBE, S.L. 1991. Polar bear management in the southern Beaufort Sea: An agreement between the Inuvialuit Game Council and North Slope Borough Fish and Game Committee. Transactions of the North American Wildlife and Natural Resources Conference 56:337-343.

NORUSIS, M.J. 1994. SPSS professional statistics 6.1. Chicago, Illinois: SPSS, Inc.
PAETKAU, D., AMSTRUP, S.C., BORN, E.W., CALVERT, W., DEROCHER, A.E., GARNER, G.W., MESSIER, F., STIRLING, I., TAYLOR, M.K., WIIG, Ø., and STROBECK, C. 1999. Genetic structure of the world's polar bear populations. Molecular Ecology 8:1571-1584.

SAS INSTITUTE INC. 1999. SAS/STAT Users' guide, Version 8. Cary, North Carolina: SAS Institute Inc.

SCHEAFFER, R.L., MENDENHALL, W., and OTT, L. 1986. Elementary survey sampling. 3rd ed. Boston, Massachusetts: Duxbury Press.

SCHLIEBE, S.L., AMSTRUP, S.C., and GARNER, G.W. 1995. The status of polar bears in Alaska 1993. Polar bears. Proceedings of the Working Meeting of the IUCN/SSC Polar Bear Specialist Group 11:125-138.

SCHWEINSBURG, R.E., FURNELL, D.J., and MILLER, S.J. 1981. Abundance, distribution, and population structure of the polar bears in the lower central Arctic islands. Northwest Territories Wildlife Service Completion Report No. 2.

SCHWEINSBURG, R.E., LEE, L.J., and HAIGH, J.C. 1982. Capturing and handling polar bears in the Canadian Arctic. In: Nielsen, L., Haigh, J.C., and Fowler, M.E., eds. Chemical immobilization of North American wildlife. Milwaukee: Wisconsin Humane Society. 267-288.

STIRLING, I. 2002. Polar bears and seals in the eastern Beaufort Sea and Amundsen Gulf: A synthesis of population trends and ecological relationships over three decades. Arctic 55 (Supp. 1):59-76.

STIRLING, I., CALVERT, W., and ANDRIASHEK, D. 1980. Population ecology studies of the polar bear in the area of southeastern Baffin Island. Canadian Wildlife Service Occasional Paper No. 44.

. 1984. Polar bear (Ursus maritimus) ecology and environmental considerations in the Canadian High Arctic. In: Olson, R., Geddes, F., and Hastings, R., eds. Northern ecology and resource management. Edmonton, Alberta: University of Alberta Press. 201-222.

STIRLING, I., SPENCER, C., and ANDRIASHEK, D. 1989. Immobilization of polar bears (Ursus maritimus) with Telazol ${ }^{\circledR}$ in the Canadian Arctic. Journal of Wildlife Diseases 25: $159-168$

STIRLING, I., LUNN, N.J., and IACOZZA, J. 1999. Long-term trends in the population ecology of polar bears in western Hudson Bay in relation to climatic change. Arctic 52(3): 294-306.

TAYLOR, M.K., SEEGLOOK, A., ANDRIASHEK, D., BARBOUR, W., BORN, E.W., CALVERT, W., CLUFF, H.D., FERGUSON, S., LAAKE, J., ROSING-ASVID, A., STIRLING, I., and MESSIER, F. 2001. Delineating Canadian and Greenland polar bear (Ursus maritimus) populations by cluster analysis of movements. Canadian Journal of Zoology 79:690-709.

TRESEDER, L., and CARPENTER, A. 1989. Polar bear management in the southern Beaufort Sea. Information North 15(4): $1-4$.

WHITE, G.C., and GARROTT, R.A. 1990. Analysis of wildlife radio-tracking data. San Diego, California: Academic Press, Inc.

ZAR, J.H. 1984. Biostatistical analysis. 2nd ed. Englewood Cliffs, New Jersey: Prentice-Hall, Inc. 